\title{
Interpretácia zjaveného Slova pomocou tradície Cirkvi - v otázke podriadenosti ženy mužovi podla Pavlovho Listu Efezanom (Ef 5, 21-33)
}

Pápežská biblická komisia vydala v roku 2014 dokument: „Inšpirácia a pravdivosț Svätého písma“. Počas jeho prípravy sa o činnost’ komisie zaujímal pápež Benedikt XVI. a jej členom v apríli 2012 povedal: „Akt zjavenia sa uzavrel smrtou posledného apoštola. Ale zjavené Slovo bolo nad’alej hlásané a interpretované živou tradíciou Cirkvi“ ${ }^{\text {.1 }}$. Pápežove slová poukazujú na skutočnost', že po apoštoloch prichádzajú krestanskí mučeníci, po nich vyznávači viery a prví cirkevní otcovia a d’alšie generácie teológov až po posledných pozoruhodných pápežov 20. a 21. storočia. Všetky tieto osobnosti zanietene a pravdivo ohlasovali a interpretovali Božie slovo a vytvárali tak živú tradíciu Cirkvi. Inšpirovanost’ a pravdivost’ sú konštitutívnym prvkom Biblie.

Živá tradícia Cirkvi v každom storočí mala tento text chránit’ od pomýlených interpretácii, ktoré sa objavovali v každej dejinnej epoche krestanstva. Vd’aka nej sa rozličné náročné problémy - biblické, historické, teologické, ale aj etické a sociálne problémy interpretovali hermeneuticky

${ }^{1}$ Benedikt XVI., Posolstvo Pápežskej biblickej komisii, http://www.tkkbs.sk/view. php? cisloclanku=20120423030. 
správne, aby im Boží lud mohol rozumiet’ a živit’ sa tak autentickým Božím slovom.

Vdaka Pápežskej biblickej komisii sa aj my tu dnes stretávame, aby sme sa zamysleli nad určitými výzvami inšpirovaného textu Biblie a pokúsili sa interpretovat' niektoré náročnejšie časti biblických textov v kontexte súčasného myslenia.

Hlavným cielom môjho referátu je poskytnút prostredníctvom tradície Cirkvi interpretáciu jedného vážneho sociálneho problému, ktorý apoštol Pavol predostrel vo svojich listoch, najmä v Liste Efezanom (Ef 5, 21-33) - a to podriadenost' ženy mužovi.

Referát rozdelujem do troch častí:

1. Pavlov pohlad na podriadenost’ ženy mužovi v historických okolnostiach 1. storočia krestanstva.

2. Pohlad tradície Cirkvi na vzţah muža a ženy od poapoštolskej doby až po pápežov 21. storočia.

3. Záverečné zhrnutie v kontexte súčasných pohladov na postavenie ženy v modernej spoločnosti.

\section{Pavlov pohl'ad na podriadenost’ ženy mužovi v historických okolnostiach}

\subsection{Storočia krestanstva podla Ef 5, 21-33}

Pavol sa v Liste Efezanom primárne venuje teológii Kristovej Cirkvi. Rozvíja úvahy o vztahu Krista a Cirkvi, a tým zároveň dáva hlbokú motiváciu manželským povinnostiam $\mathrm{v}$ rámci teológie krestanského manželstva.

Text Ef 5, 21-33 vytvára vo vnútri tejto časti literárny celok, ktorým sa otvára tzv. rodinný kódex alebo tabula domácich povinnostî ${ }^{2}$. Tento literárny žáner používali najmä grécki autori, ktorí sa obracali na rôzne kategórie ludí vo vztahu $\mathrm{k}$ ich spoločenskému postaveniu a vymenúvali zoznamy ich povinností.

${ }^{2}$ Porov. J. Heriban, Príručný lexikón biblických vied, Rím 1992, s. 897-898. 
Židovsko-helenistickí autori ako Filon z Alexandrie a Jozef Flavius vymenúvajú zoznamy povinností napr. v rodine a v domácnosti pomocou biblického modelu Božích prikázaní. Filon vyratúva v príkaze ctit si rodičov povinnosti, ktoré majú mladí voči starým, sluhovia voči Pánom a naopak. Rozlišuje tak, podobne ako Pavol, tri kategórie subjektov povinností: muž - žena, otcovia - deti, páni - sluhovia ${ }^{3}$.

Krestanská tradícia prevzala manuály povinností grécko-helénskeho prostredia vdaka židovskej diaspore, ale s vlastnou motiváciou inšpirovanou zo skúsenosti viery. A toto je zjavné najmä v Liste Efezanom, kde Pavol do vnútra rodinného kódexu vkladá katechézu, zameranú na vztah medzi Kristom a Cirkvou (Ef 5, 26-32). Tento vztah otvára Pavlovo chápanie kristológie a ekleziológie. Autor sa odvoláva na Krista ako na "hlavu Cirkvi", "Spasitela svojho tela".

Rané krestanstvo teda akoby "uzákonilo" súveký manželský a rodinný kódex ako program pre pokojný a perspektívny chod krestanskej rodiny - pravda, s vlastnou teologickou a morálnou náplňou.

Tento úvod sme si dovolili urobit preto, aby sme poukázali na to, že apoštol Pavol bol mužom, ktorý nežil odtrhnuto od kontextu svojej doby. Naopak, dokázal so živým záujmom sledovat široké súvislosti vtedajšieho života a využívat ich pre evanjelizáciu; stačí spomenút aspoň jeho reč v aténskom areopágu (porov. Sk 17, 16-34). V tomto zmysle dokázal prakticky uvažovat aj o krestanskom manželstve a rodinnom živote a zaoberal sa témami, ktoré boli v jeho dobe pálčivé.

V období začínajúceho krestanstva sa napr. vela diskutovalo o téme slobody a rovnosti, ako aj o tom, že muž má milovat svoju ženu. V helenisticko-rímskej diskusii o poriadku ludského spolužitia nachádzame texty, ktoré korigujú vztahy medzi extrémnymi stanoviskami, t.j. medzi absolútnou rovnostou a medzi tradičným poňatím panovania $\mathrm{v}$ záujme domácej svornosti ${ }^{4}$.

\footnotetext{
${ }^{3}$ Porov. R. Fabris, Il matrimonio cristiano, [v:] A. Sacchi, Lettere Paoline e altre Lettere, vol. VI., Leumann-Torino 1996, s. 526.

${ }^{4}$ Porov. R. Hoppe, List Efezanům. List Kolosanům, Kostelní Vydří 2000, s. 66.
} 
Preto chceme správne pochopit myslenie sv. Pavla načrtnuté v jeho listoch, najmä však v Ef 5,21-33. Chceme objasnit delikátny problém podriadenosti ženy mužovi v manželstve. Pokúsime sa vysvetlit myslenie sv. Pavla načrtnuté v Liste Efezanom ${ }^{5}$.

Verš 21-22

Treba si vyjasnit, že Pavol najprv oslovuje miestnu cirkev ako celok: „podriadujte sa jedni druhým” (porov. tiež Rim 13, 1-5; Tit 3, 1; 1 Pt 2, 13). Toto podriadovanie sa má diat $\mathrm{v}$ poddanosti každého krestana Kristovi ako hlave. Čo znamená grécke sloveso „podriad’ovat sa“? Toto sloveso je súčastou helénskej tradície rodinných kódexov, kde sa hovorí: „Patrí sa, aby manželka bola podriadená mužovi”' ${ }^{\text {. }} \mathrm{V}$ takomto prostredí toto sloveso označuje podriadenost toho, kto sa správa vhodným spôsobom, zodpovedajúco svojej úlohe a postaveniu. "Sloveso podriadovat sa nachádzame u Pavla 23-krát. Vždycky vyjadruje podriadenost tým, ktorí si ju zasluhujú, a to bud' kvôli svojim vnútorným kvalitám, alebo častejšie kvôli postaveniu, ktoré zastávajú"8.

${ }^{5}$ Znenie textu Ef 5, 21-33: „ "1 a podriadujte sa jedni druhým v bázni pred Kristom. 22 Ženy svojim mužom ako Pánovi, ${ }^{23}$ lebo muž je hlavou ženy, ako je aj Kristus hlavou Cirkvi, on, Spasitel tela. ${ }^{24}$ Ale ako je Cirkev podriadená Kristovi, tak aj ženy mužom vo všetkom. ${ }^{25}$ Muži, milujte manželky, ako aj Kristus miluje Cirkev a seba samého vydal za ňu, ${ }^{26}$ aby ju posvätil očistným kúpelom vody a slovom, ${ }^{27}$ aby si sám pripravil Cirkev slávnu, na ktorej niet škvrny ani vrásky ani ničoho podobného, ale aby bola svätá a nepoškvrnená. ${ }^{28}$ Tak sú aj muži povinní milovat', svoje manželky ako vlastné telá. Kto miluje svoju manželku, miluje seba samého. ${ }^{29}$ Ved' nik nikdy nemal v nenávisti svoje telo, ale živí si ho a opatruje, ako aj Kristus Cirkev, ${ }^{30}$ lebo sme údmi jeho tela. ${ }^{31}$ Preto muž zanechá otca i matku a pripúta sa k svojej manželke a budú dvaja v jednom tele. ${ }^{32}$ Toto tajomstvo je velké; ja hovorím o Kristovi a Cirkvi. ${ }^{33}$ Ale aj vy, každý jeden nech miluje svoju manželku ako seba samého. A manželka nech si ctí muža“.

${ }^{6}$ Porov. R. Fabris, Il matrimonio cristiano, s. 529.

${ }^{7}$ Porov. tamtiež, s. 528-534.

${ }^{8}$ A. S. Vood, Ephesians, Grand Rapids, Michigan 1976, s. 75 (The Expositor's Bible Commentary, 11). 
V krestanskom kontexte a v kristologických súvislostiach - termín „byt podriadený” zodpovedá postoju vzájomnej služby, ktorý Pavol vyžaduje od krestanov ako vyjadrenie lásky (porov. Gal 5, 13-14). Vzájomná podriadenost', ktorú si majú krestania v spoločenstve poskytnút', sa zakladá na viere v Ježiša Krista, jediného Pána, a uskutočňuje sa vo vzájomnej službe, inšpirovanej láskou? .

Pavol vidí aj manželstvo vo vztahu Cirkvi ku Kristovi. Teologicky tu teda ide $\mathrm{v}$ skutočnosti o Cirkev. Táto analógia poukazuje na velkú vznešenost̉ manželstva a vzájomného vztahu medzi mužom a ženou.

\section{Verš 23}

Predchádzajúci verš smeruje k tomuto: „lebo muž je hlavou ženy, ako je aj Kristus hlavou Cirkvi, on, Spasitel' tela" (porov. 1 Kor 11, 3 - bez ohladu na Cirkev). Je tu niekolko pozoruhodných aspektov: „Hlava” tu nie je len označením vládnutia, ale podla 4,15n je aj zárukou funkčnosti celého organizmu, pričom tento obraz má teologický význam, konštatuje vo svojom komentári Rudolf Hoppe ${ }^{10}$. Formulácia tohto verša prezrádza, že ide o tradičné konštatovanie, ako sa $\mathrm{v}$ tom čase chápal i prijímal vo vtedajšej spoločnosti aj v krestanskej domácnosti vzájomný vzţah medzi mužom a ženou. Autor sa nezastaví pri porovnaní vztahu muža a ženy, Krista a Cirkvi, ale ide d’alej. Prechádza ku Kristovmu vykupitelskému dielu voči Cirkvi.

\section{Verš 24}

„Ale ako je Cirkev podriadená Kristovi, tak aj ženy mužom vo všetkom". Verš 24 potvrdzuje verš 22 , ktorý je prebratý z Kol 3, 18 a kristologicky zdôvodnený je aj rozšírený o výraz: „vo všetkom”. Podriadenost Cirkvi k zachraňujúcemu Kristovi takto určuje aj pomer ženy voči mužovi. Isté je, že pre dnešnú dobu je toto vyhlásenie trochu poburujúce. „Predovšetkým treba mat na pamäti, že ide o dobový text. Pavol nežije v dvadsiatom (teraz už v dvadsiatom prvom - pozn. prekl.) storočí, v ktorom sú zaručené (aspoň teoreticky) civilné práva a právnická rovnost’

\footnotetext{
${ }^{9}$ Porov. R. Fabris, Il matrimonio cristiano, s. 529.

${ }^{10}$ R. Hoppe, List Efezanům. List Kolosanum, s. 67.
} 
medzi mužom a ženou. Pavol žije v kultúre, ktorá nepozná toto právo na právnej úrovni a vo vztahu $\mathrm{k}$ tomuto právu zavádza dovtedy nemyslitelnú novost', ktorá nepriamo, ako je to aj v prípade Listu Filemonovi vzhladom na otrokov, zavádza rovnost práv a povinností medzi mužom a ženou v manželstve (aj ked' nie na právnej úrovni)"11.

Treba si však všimnút, že Pavol hovorí o takejto podriadenosti len v kontexte krest’anského manželstva. Manželky majú byṫ podriadené len „svojim” manželom (porov. Kol 3, 18). Nie je tu zahrnuté tvrdenie, že by bola žena menejcenná, alebo že by všetky ženy mali byt podriadené všetkým mužom. Tým, že žena poslúcha svojho muža, poslúcha samého Krista, ktorý posvätil manželský zväzok. Táto podriadenost' je teda výrazom slobodnej vôle, nie je nanútená. Je predpokladom uzavretia manželstva. Krestanská žena, ktorá sa v rámci tohto zväzku zaväzuje k poslušnosti, tak robí preto, že jej slub je daný Pánovi ${ }^{12}$.

\section{Verš 25}

Týmto veršom autor prechádza k napomínaniu mužov. Podriadenosti ženy má zodpovedat' láska mužov. Motivácia, ktorú používa autor v liste, ked' ide o mužove povinnosti voči žene, gréčtina vyjadruje slovesom „milovat" (agapao). Je to slovo, ktoré označuje najvyšší stupeň krestanskej lásky ${ }^{13}$. Aj toto sloveso sa objavuje v rodinných kódexoch grécko-helénskeho prostredia, hoci menej, ako sloveso „mat rád“ (fileo $)^{14}$.

V tomto verši sa tiež vztah muža k žene chápe pomocou obrazu KristusCirkev. Pavol takto prináša do teológie manželstva a rodiny nový prvok: analogické prepojenie muž-žena a Kristus-Cirkev. Ked'hovorí o mužovi, aby miloval ženu, nehovorí nič nové, lebo v grécko-rímskej antickej literatúre sa nachádza vela etických napomenutí o povinnosti muža, aby miloval svoju ženu ${ }^{15}$. Ale niečím novým je Pavlovo poukázanie na mystický rozmer tejto lásky.

\footnotetext{
${ }^{11}$ G. Ravasi, Lettere agli Efesini e ai Colossesi, Bologna 1994, s. 79.

12 Porov. A. S. Vood, Ephesians, s. 75.

${ }^{13}$ Porov. tamtiež, s. 76.

${ }^{14}$ Porov. R. Fabris, Il matrimonio cristiano, s. 530.

${ }^{15}$ Porov. R. Hoppe, List Efezanum. List Kolosanum, s. 68.
} 
Niektorí krestania si mysleli, že Pavol mal k manželstvu negatívny vztah (porov. 1 Kor 7, 32-38). No z verša 25 vyplýva, že Pavol mal k manželstvu velmi pozitívny vztah. Ved' ho pôsobivým obrazom prirovnáva k vztahu medzi Kristom a jeho Cirkvou. Tieto verše odrážajú Pavlovo jasné teologické chápanie manželstva, ktoré je pre neho svätá jednota, živý symbol a drahocenný vztah, ktorý potrebuje obetavú starostlivost. ${ }^{16}$

Ked'Pavol radí, ako majú muži milovat svoje manželky $(5,25-30)$, používa pritom dvakrát tol'ko slov, ako ked' manželkám hovorí, že sa majú podriad'ovat’ svojim manželom. Preto žena nemusí mat' strach podriadit’ sa mužovi, ktorý ju takto miluje.

Pavlova náuka o manželstve v Liste Efezanom (porov. 5, 21-33) je dôkladnejšie a pozitívnejšie vypracovaná, ako napr. v Prvom liste Korint’anom, v kapitole 7. Vzt’ah Krista a Cirkvi je pre Pavla vel'kým tajomstvom. Ale i vztah muža a ženy v manželstve vidí ako „mysterium” (porov. 5, 32). Podla neho manželstvo v tomto svete aktualizuje "mysterium salutis” („tajomstvo spásy“).

Pavol vidí ludské manželstvo v súvislosti Krista a Cirkvi, čo znamená, že vzt’ah muža a ženy v manželstve je súčastou tohto mystéria. A tak manželstvo poukazuje na zmluvu Boha a vyvoleného národa, zmluvu Ježiša Krista a jeho Cirkvi a na akúkolvek činnost’ Božiu, ktorú v dejinách spásy urobil, robí a bude robit' v prospech človeka. Ked’ teda manželstvo muža a ženy má účast' na eschatologickej zmluve, potom je, teologicky povedané, aj obrazom „zmluvy novej a večnej”, t.j. vel'konočnej.

Toto je stručné zhrnutie Pavlovej teologickej argumentácie v texte Ef 5, 21-33, ktorá poukazuje na mystickú vznešenosț manželstva.

Na doplnenie ešte môžeme spomenút aj pastorálnu konštitúciu Gaudium et spes, ktorá túto Pavlovu argumentáciu vysvetluje takto: „Lebo ako sa kedysi Boh ponáhlal v ústrety svojmu ludu zmluvou lásky a vernosti, tak teraz Spasitel' ludí a Ženích Cirkvi ide naproti krestanským

${ }^{16}$ Průvodce životem, Pavliov list do Efezu, Praha 1995, s. 37. 
manželom sviatostou manželského stavu. A zostáva nad’alej s nimi, aby manželia jeden druhého vo vzájomnej oddanosti navždy verne milovali, ako si on zamiloval Cirkev a seba samého obetoval za ňu. Pravá manželská láska sa pripája na lásku Božiu a vedie i obohacuje ju vykupitel’ská moc Kristova a spasitel’ná moc Cirkvi, aby sa manželia účinne priviedli k Bohu" (GS, bod48).

Pavlova náuka o manželstve vychádza teda zo snúbeneckej lásky Krista a Cirkvi (Ef 5, 33). Pre Pavla je to aj model pre manželstvo. Manželský vztah sa buduje výlučne na láske muža a ženy. Muži dostávajú úlohu milovat’ svoje manželky “ako Kristus svoju Cirkev” (5, 25). Žena sa stáva telom manžela, ako Cirkev je telom Kristovým. "Muž je totiž hlavou ženy, podobne, ako je Kristus hlavou Cirkvi, sám Spasitel' svojho tajomného tela" $(5,23)$. Podla Pavla symbolický význam manželstva aktualizuje dielo spásy. Krestanské manželstvo je obrazom a miestom jednoty Krista a Cirkvi. Uvedené texty v Novom zákone vysvetlujú starozákonné chápanie manželstva vo svetle Kristovej vykupitel’skej lásky k človeku. Manželstvo teologicky vnímané nás vedie k eschatologickej hostine (porov. Zjv 19, 6-9; 21, 2-9). Text Ef 5, 21-33 sa považuje za centrálny v katalogizácii manželských i rodinných pravidiel, pretože je v ňom výnimočným spôsobom vyjadrená snúbenecká láska Krista a Cirkvi ${ }^{17}$.

\subsection{Krátke posolstvo pre manželov z Listu Efezanom}

Poznajúc mentalitu súčasného sveta, môžeme konštatovat', že nielen neveriaci, ale ani krestanskí manželia na rozhraní 20. a 21. storočia neprijímajú slová apoštola Pavla z Listu Efezanom. V dobe, v ktorej sa pokladá za nutný predpoklad správneho vzt’ahu medzi mužom a ženou len vzájomné partnerstvo, tažko sa prijíma toto inšpirované Božie slovo o podriadenosti ženy - alebo (ak vernejšie reprodukujeme toto Božie slovo) - o vzájomnej podriadenosti muža a ženy. Mnohí exegéti odporúčajú chápat tento text $\mathrm{z}$ hladiska časového horizontu 1. storočia po Kristovi, a tým sa tieto miesta v Liste Efezanom zrelativizujú.

${ }^{17}$ Porov. J. R. V. Stott, Výklad epištoly Efežanům, Praha 1992, s. 201-203. 
No predsa sa odvažujeme tvrdit', že jediné správne chápanie týchto veršov je s vierou ich prijat’ ako inšpirované Božie slovo a pochopit ho pomocou predchádzajúceho i následného vysvetlenia.

Konštatovali sme teda, že vzájomná podriadenost' tých, čo veria $v$ Krista, sa priamo odráža v manželskom vztahu (v. 22). Pre manželky „podriadenost" manželovi je teda konkrétne a existenciálne vyjadrenie spôsobu, ktorým ony realizujú záväzok prevzatý v krste - „kráčat’ v láske” (agapao - porov. Ef 5,2). Manželská podriadenost̉ krestanských žien má základ vo vztahu s Pánom (Kyrios) a je zdôvodnená: „lebo muž je hlavou ženy, ako je aj Kristus hlavou Cirkvi, on, Spasitel' tela" (verš 23). V týchto veršoch, tak ako v 1 Kor 11, 3 nájdeme spojené argumenty kulturálnej antropológie s argumentami kristológie a ekleziológie. ${ }^{18}$

Tvrdenie, podla ktorého je muž hlavou ženy, pochádza $\mathrm{z}$ antického prostredia tak grécko-helenistického, ako aj židovského; zatial' čo vyhlásenie, že Kristus je „hlavou Cirkvi”, je charakteristika kristologického a ekleziologického videnia listu Kolosanom a Efezanom (Kol 1, 18; 2, 19; Ef 1, 22; 4, 15; porov. aj 1 Kor 11, 3). Ale tu sa upresňuje: Kristus je „hlavou” Cirkvi - tela, nakolko je jej „Spasitelom.“19 Spôsob, akým Kristus vykúpil Cirkev, je ilustrovaný hned' d’alej vo výzve mužom, aby milovali svoje ženy ako Kristus - až po sebaobetovanie (verš 25).

Na základe kristológie a soteriológie listu nadobúda teda podriadenost’ žien mužom a aj láska mužov voči ženám novú platnost' - ide o vzájomnú podriadenost’.

Ak chceme uzavriet' Pavlovu ideu vyjadrenú v Ef 5, 22-24, môžeme konštatovat', že apoštol sa tu obracia najprv na tú stránku, ktorej v manželstve, podla prirodzenosti prináleží poslúchat - teda na ženu. Ženy majú vidiet’ vo svojom mužovi ako v hlave rodiny analógiu s Kristom, hlavou a Spasitelom Cirkvi (tela) a napodobňovat' svojou poslušnostou voči mužovi poslušnost' Cirkvi voči Kristovi; a majú poslúchat svojho manžela vo všetkom, čo sa neprotiví Božiemu zákonu. Je to zaiste pre ženu tažká požiadavka.

\footnotetext{
${ }^{18}$ Porov. J. Dolista, Naděje vložená do manželství, Olomouc 1994, s. 40-42.

${ }^{19}$ Porov. tamtiež.
} 
Ale či nie je rovnako tažká úloha muža, ktorý má robit kvôli nej to, čo urobil kvôli svojej Cirkvi Kristus, ktorý i samého seba vydal za ňu, aby ju silou tejto svojej obety posvätil, očistil v krstnom kúpeli, v zdroji jej duchovnej krásy? ${ }^{20}$ A teda aj mužova láska sa podriad’uje v službe svojej manželke. Podriadenost' manželov je vzájomná.

V tomto vidíme geniálnost’ vysvetlenia vzájomných vztahov medzi manželmi, ktoré nie sú rovnostárske, ale komplementárne. A preto neodporujú faktickej rovnoprávnosti a rovnakej dôstojnosti muža a ženy. Naopak, aj mužovi, aj žene pripisujú vlastnú špecifickú a nenahraditel’nú úlohu, ktorú im daroval Boh.

\section{Pohlad tradície Cirkvi na vzt’ah muža a ženy od poapoštolskej doby až po pápežov 21. storočia}

\section{1. Žena v izraelskej kultúre ${ }^{21}$}

Biblické posolstvo o žene bolo u Izraelitov chápané v kontrastoch. Na jednej strane je žena postavená na úroveň muža v zmysle biblického rozprávania o stvorení: „A stvoril Boh človeka na svoj obraz, na Boží obraz ho stvoril, muža a ženu ich stvoril“ (Gn 1,27). Aj mnohé dalšie biblické texty hovoria o dôležitosti ženy v judaizme (napr. Miriam, Rebeka, Ester, Judita, Debora, Anna, Sára, Rút...).

Avšak na strane druhej - z biblických textov sa odvodzovala nadvláda muža nad ženou (stvorenie Evy z Adamovho rebra, Eva sa nechala prvá zviest’ diablovi, muž bude vládnut’ nad ženou...). V právnickej rovine žena nemá v izraelskej komunite takmer žiadnu dôležitost'. Podla zákonodarstva žena nebola rovnoprávna s mužom ${ }^{22}$. Ako manželka je úplne podriadená manželovi. V Starom zákone ju otec mohol dat za snúbenicu alebo

\footnotetext{
${ }^{20}$ Porov. J. R. V. Stott, Výklad epištoly Efežanom, s. 205-210.

${ }^{21}$ Porov. M. Fulla, Antropológia ženy, Bratislava 2004, s. 22-26.

${ }^{22}$ X. Léon-Dufour, Slovník biblickej teológie, Zagreb 1990, s. 1606.
} 
dokonca konkubínu, komu chcel (porov. Gn 29). Podla Tóry žena patrí mužovi, ktorý je jej absolútnym pánom a ktorého je povinná poslúchat; ba dokonca podla Desatora sa žena javí ako vlastníctvo manžela, o ktoré ho nikto nesmie obrat' („Nepožiadaš dom svojho blížneho, ani nepožiadaš manželku svojho blížneho, ani jeho sluhu, ani jeho slúžku, ani vola, ani osla, ani nič, čo je tvojho blížneho!“ Ex 20, 17).

Manželský a rodinný život v Izraeli bol teda postavený na čisto patriarchálnych základoch. Muž bol protagonistom rodinného aj spoločenského života. Mal dokonca právo na polygamiu.

V porovnaní s okolitými pohanskými národmi však žena v izraelskej spoločnosti predsa požívala ovela väčšiu mieru úcty, ale aj ochrany, ktorá jej patrila ako príslušníčke slabšieho ženského pokolenia. Tóra pripisuje velkú dôležitost' úlohe ženy v domácnosti, lebo rodí deti a vychováva ich. Kniha príslovía Kniha Sirachovho syna oslavuje hebrejskú ženu, lebo zaručuje kontinuitu potomstva a poskytuje pomoc manželovi (Prís 18, 22; Sir 36, 20-28). Vyzdvihovanie materstva, plodnosti a materinskej lásky (2 Sam, 21, 8-10) je motivované vernostou manželovi, otcovi detí; ak to však žena nesplňa, patrí jej pohŕdanie až zavrhnutie. Zákon dokonca požadoval smrt’ za cudzoložstvo.

Jednoznačne možno konštatovat', že starozákonná izraelská spoločnost’ je výrazne maskulinistická. Toto silne vplývalo aj na náboženský život. Biblickú rovnost' medzi pohlaviami zatienila staroveká orientálna mentalita. Aj ked' postavenie hebrejskej ženy by sa mohlo javit’ výhodnejšie ako situácia žien okolitých pohanských národov, predsudky a kultúrne podmienenosti v izraelskom vedomí zabránili tomu, aby sa v judaizme začala vyvíjat teológia ženy podla knihy Genezis a aby sa na ženu pozeralo personalisticky.

\section{2. Žena v antickom Grécku a Ríme}

Napriek vyspelej antickej gréckej kultúre postavenie ženy bolo v tejto spoločnosti menejcenné. Dominantné postavenie mali muži, ženu považovali podla mytológie za pôvodkyňu zla. Jej úloha spočívala v starostlivosti o domácnost' a v rodení detí.

Rímska žena sa v porovnaní s izraelskou či gréckou ženou teší odlišnému postaveniu. Od najstarších čias si Rimania uvedomovali kúzlo 
domáceho života, ktorý prežívali s vlastnou manželkou - milou spoločníčkou a spolupracovníčkou ${ }^{23}$. Niektoré ženy boli dokonca rešpektované aj na verejnosti. Napriek tomu nemožno povedat, že vo všeobecnosti by mala rímska žena podstatne väčšiu úctu v porovnaní s gréckou. Z právneho hladiska môžeme povedat', že prax monogamného manželstva v rímskej spoločnosti bola založená na prísnej patriarchálnosti. Aj rímska spoločnost' bola jasne maskulinistická. Hlava rodiny má moc nad životom a smrtou ženy. Nevera ženy bola trestaná smrtou. Všetky ženy patrili pod tútorstvo mužov kvôli tzv. duševnej slabosti a nestálosti ženského pohlavia. Pravý Riman sa ženil bez lásky a miloval bez jemnosti a rešpektu.

Prevládajúci antifeministický postoj výstižným spôsobom dokumentuje latinská literatúra. Rímski spisovatelia opisujú mnohé ženy ako bytosti bez spirituálnych impulzov, poznačené erotizmom a inštinktívnostou. Vo všeobecnosti môžeme povedat, že hoci v Ríme nastal určitý posun v postoji k žene v porovnaní s gréckym a hebrejským svetom, jej postavenie sa podstatne nemení ani v rímskom svete.

\section{3. Žena v krestanskom staroveku - v prvotnej Cirkvi ${ }^{24}$}

Ježiš Kristus prináša priam revolučný oslobodzujúci postoj k žene, ktorý predstavoval dramatický obrat v hebrejskom svete. Ježiš sa správal k ženám s úctou, ženy patrili do jeho sprievodu, sprevádzali ho na krížovej ceste, boli prvými zvestovatel'kami jeho zmŕtvychvstania. V prvotnej Cirkvi viedol Ježišov postoj k ženám k prechodu od hierarchického spoločenstva moci k bratskému spoločenstvu recipročnej služby na základe sviatosti krstu - a ten prijímali rovnako muži aj ženy. Preto sa uzavreté liturgické zhromaždenie otvorilo aj voči ženám. Ženy mohli vykonávat’ úlohy primárnej dôležitosti na základe živej viery a odvážneho svedectva (mučenice, prorokyne, misionárky, diakonky, charizmatičky). Z množstva novozákonných žien vieme o krásnych osobnostiach, ako boli Féba, Priska, Evódia, Synticha, Mária, Júlia, Trifena, Trifoza, Persida, Lýdia (porov. List Rimanom...) Boli to ženy - sestry pochádzajúce z komunít

\footnotetext{
${ }^{23}$ Porov. U. E. Paoli, Vita romana, Milano 1982, s. 85-92.

${ }^{24}$ Porov. M. Fulla, Antropológia ženy, s. 38-40.
} 
založených apoštolom Pavlom. O úprimnej apoštolskej spolupráci mužov a žien svedčia aj Skutky apoštolov (Pavol a Akvilas s Priskou; Lýdia; Nymfa; Klaudia...). A tak na základe novozákonných svedectiev môžeme tvrdit, že v prvotnej Cirkvi sa začal realizovat' rovnocenný vztah muž-žena ${ }^{25}$.

Avšak napriek novému chápaniu dôstojnosti ženy prvotná Cirkev sa nedokázala celkom odpútat od patriarchálnej kultúry. Tento problém je evidentný u samotného apoštola Pavla, ktorý na jednej strane prehlasuje prekonanie každej diskriminácie, vrátane pohlavia: „Už niet Žida, ani Gréka, niet otroka ani slobodného, niet muža a ženy, lebo vy všetci ste jeden v Kristovi Ježišovi“ (Gal 3, 28); dokonca sám spolupracuje so ženami. Na druhej strane odsúva ženy do pozície mlčiacich (1 Kor 14, 34-35) a poukazuje na to, že nie muž bol stvorený kvôli žene, ale žena kvôli mužovi (1 Kor 11, 10).

Prenikanie krestanstva do grécko-rímskeho sveta bolo poznačené pohanskou kultúrou, v ktorej prevažovala pesimistická idea ženy. Tá redukovala ženy poväčšine na ich sexuálnu funkciu, a preto sa ženy stávali predmetom opovrhovania novopytagorovských a stoických filozofov.

Je dôležité uvedomit’ si, že v takomto kultúrnom kontexte pôsobili cirkevní otcovia. Nemali to lahké, hoci si uvedomovali novost’ krestanskej koncepcie ženy vyjadrenej Ježišom Kristom a evanjelistami. A zastávali - ako celá krestanská tradícia - náuku, podla ktorej žena ako človek Bohom stvorený a Kristom vykúpený je rovná mužovi a povolaná k tej istej dokonalosti.

Profesor Mattioli pri komentovaní dokumentu Mulieris dignitatem hovorí, že sa postupne vytvorila séria tradičných sloganov, ktoré vplývali na život ženy: má menšiu dôstojnost', nie je schopná učit', vykonávat’ moc, je podriadená mužovi vo všeobecnosti aj v manželstve ${ }^{26}$.

Napriek tejto nedôvere voči žene, ktoré nájdeme aj vo vyjadreniach niektorých cirkevných otcov, predsa sa viacerí pokúšali presadit’ v pohanskej kultúre krestanské posolstvo dôstojnosti ženy.

${ }^{25}$ A. Weiser, Die Frau im Umkreis Jesu und in den urchristlichen Gemeinden, [v:] H. Pissarek-Hudelist (Hrsg.), Die Frau in der Sicht der Anthropologie und Theologie, Düsseldorf 1989, Düsseldorf 1989, s. 127-137.

${ }^{26}$ U. Mattioli, La tradizione nella „Mulieris dignitatem“, Genova 1991, s. 15-19. 
Klement Alexandrijský tvrdí, že Logos je pedagógom aj mužom, aj žien, a preto sú obidve pohlavia povolané k rovnakým cnostiam. ${ }^{27}$

Sv. Bazil vkladá do úst žene - mučenici slová: „Sme z rovnakého cesta ako muži. Boli sme stvorené na Boží obraz a podobu tak ako oni... Nemáme rovnakú prirodzenost ako muž? “28

Sv. Ján Zlatoústy hovorí o postavení muža a ženy v manželstve a rodine: „Žena má v mnohom prevyšovat ostatné údy tele, nielen pre jej pozíciu, ale pre schopnost predvídat a riadit ostatné údy, ako to robí kormidelník na lodi, lebo počúva svojho kapitána ako žena svojho manžela v rodine. Muž teda podobne ako hlava nevyniká natolko pre úctu, ktorá sa mu dostáva, ako skôr pre jeho konanie a starostlivé spravovanie rodiny. Iba v takomto zmysle riadime ženy - prevyšujeme ich nie tým, že si od nich nárokujeme väčšiu úctu, ale tým, že im preukazujeme dobro.“ (Homília k 2 Sol 5, 5)

Sv. Hieronym hovorí: „Pokiali ide o svätost' a bezúhonnost manželstva, pridŕžaj sa pravidla, ktoré nám zanechal svätý apoštol: [...] nech sa celá rodina $\mathrm{z}$ tvojho príkladu naučí, ako si ho treba ctit. Poslušnostou ukáž, že on je hlavou rodiny a svojou skromnostou vyzdvihni jeho dôležitost'. Ty sama budeš tým váženejšia, čím viac si ho budeš uctievat, pretože hlavou ženy je muž (Ef 5,23$)^{\text {“29. }}$.

Sv. Ambróz reaguje na mentalitu vtedajšej spoločnosti a mužom odkazuje: „Nie si pánom, ale manželom; nedostal si otrokyňu, ale manželku. [...] Odplácaj sa jej pozornostou a bud’ jej vdačný za lásku“30.

Velikánmi krestanskej filozofie a teológie sú sv. Augustín a sv. Tomáš. Aj ked Augustín je starovekým autorom a od Tomáša ho historicky delí 8 storočí, ich vplyv na západné filozoficko-teologické myslenie je dalekosiahly a má spoločné črty. Vo svojej antropológii analyzovali aj vztah muža a ženy.

${ }^{27}$ Klement Alexandrijský, Paedagogus I., 4., s. 120-131 (Corpus Christianorum Series Latina, 70).

${ }^{28}$ Bazil Velký, Homilia in martyrium Julittam 2, [v:] Patrologia Graeca, vol. 31, s. 241.

${ }^{29}$ Hieronym, Listy IV, 148, 25-27 (Celanzii).

${ }^{30}$ Ambróu, Hexameron V, 7, 19 (Corpus Scriptorum Ecclesiasticorum Latinorum, $32, \mathrm{I}, 154)$. 
Viaceré kritické štúdie potvrdzujú, že ich antropológia je poznačená androcentrizmom vtedajšej spoločnosti a je vypracovaná jednostranne z pohladu muža. Augustín aj Tomáš vychádzali z princípu podriadenosti ženy mužovi, ktorý je podla nich v súlade s poriadkom stvorenia a v súvise $s$ dôsledkami dedičného hriechu. Avšak Kristom uskutočnené dielo vykúpenia obnovilo pôvodný poriadok stvorenia, ked'bol človek stvorený na Boží obraz. Preto sa v dôsledku vykúpenia, teda $v$ poriadku spásy, muž a žena dostávajú na rovnakú úroveň.

Učenie sv. Augustína aj sv. Tomáša hlboko a dlhodobo ovplyvňovalo názory na postavenie muža a ženy v Cirkvi a spoločnosti v tom zmysle, že muži majú dominantné postavenie a ženy sú ich podriadenými pomocnicami. Avšak ich idea, že človek - muž a žena - sú priamo Bohom stvorení a zameraní na návrat $\mathrm{k}$ Bohu, otvorila perspektívu pre dalšie reflexie o reciprocite muža a ženy, ako aj o dôstojnosti a nezastupitelnej hodnote ženy ${ }^{31}$.

\subsection{Vzt’ah muža a ženy v učení pápežov 20. a 21. storočia}

Na vzmáhajúci sa feminizmus a úpadok manželského a rodinného života reagoval Pius XII. okrem iného aj viacerými príhovormi mladomanželom v roku $1942^{32}$. V kontexte tažkého vojnového obdobia nazval ich spolužitie „bojom dvoch odvážnych a navzájom zjednotených duší, ktoré idú v ústrety skúškam a náporom..."

Pápež vyzdvihuje poslanie ženy v tomto zápase o štastnú krestanskú rodinu: „žena viac ako muž môže prispievat' k rodinnému štastiu. Úlohou muža predovšetkým je zabezpečit’ existenčné prostriedky pre rodinu... Žene zas patrí tisíc drobných starostí a pozorností každodenného života, ktoré vytvárajú rodinnú atmosféru... Činnost’ manželky má byṫ činnostou udatnej ženy, ktorú velebí Písmo (Prís 31, 11-12)... Muž ju v tejto úlohe nikdy nebude môct' zastúpit'. Toto poslanie jej bolo dané od prírody a zjednotením sa s mužom..." (Audienčný príhovor 25. februára 1942).

\footnotetext{
${ }^{31}$ Porov. M. Fulla, Antropológia ženy, s. 49-52.

${ }^{32}$ Nasledujúce citované texty pochádzajú zo samizdatovej publikácie z archívu autora: Pius XII., Príhovory mladomanželom.
} 
V dalšom príhovore Pius XII. vyzdvihuje spoluprácu manželov s Bohom, ale aj medzi sebou navzájom pri plodení detí a ich výchove, ako aj pri celkovom chode rodiny. $\mathrm{V}$ dalšom sa venuje vzájomnému vychádzaniu si manželov v ústrety, poukazuje na dôležitost' drobných prejavov pozorností... Pius XII. prejavil nielen teologickú híbku pri charakterizovaní krestanského manželstva, ale aj znalost’ psychológie a praktických stránok rodinného života.

$\mathrm{V}$ audienčnom príhovore $\mathrm{z}$ 15. apríla 1942 sa zameriava na rozdielnosti medzi mužom a ženou a na podriadenost ženy mužovi, o ktorej píše Pavol v 1 Kor 11, 3. Pozitívnym spôsobom vyjadruje obdiv nad odlišnostami a komplementárnostou muža a ženy. Povzbudzuje ich, aby využívali svoje dary pre vzájomné dobro. Postavenie muža ako hlavy nemá ženu ponižovat', ale má muža viest' k tomu, aby svoju silu a zdatnost' vložil do služby manželke a rodine.

Pius XII. v reakcii na otázku podriadenosti ženy mužovi v zmysle Pavlových listov zaznamenáva d’alší posun učenia Cirkvi smerom k spravodlivému vyváženému postoju, ktorý oceňuje dôstojnost', hodnotu a rovnocenný prínos ženy aj muža do vzájomného vzt’ahu.

Pápež sv. Ján Pavol II. predstavuje vrchol reprezentatívneho učenia Cirkvi o manželstve a rodine na prelome 20. a 21. storočia. V otázke podriadenosti ženy mužovi vyzdvihuje teologický význam manželského spojenia ako symbolu a obrazu vztahu medzi Kristom a Cirkvou. Jeho prevratná teológia tela poukazuje na mystickú hodnotu manželského communio personarum. Preto aj vzt’ah medzi mužom a ženou Ján Pavol II. chápe a prezentuje predovšetkým ako duchovnú hodnotu, a nie ako problém disciplíny či mentorského prístupu.

„Mocou sviatostnej povahy svojho manželstva sú manželia navzájom spojení nerozlučitel’ným putom. Tým, že k sebe patria, vyjadrujú prostredníctvom sviatostného znaku samo spojenie Krista s Cirkvou. [...] Manželská láska predstavuje takú úplnost', v ktorej dostávajú miesto všetky zložky osobnosti - požiadavky tela i pudu, sily zmyslov a citov, túžby ducha a vôle. Táto láska smeruje k čo najhlbšej osobnej jednote, ktorej nejde len o telesné spojenie, ale vytvára jedno srdce a jednu dušu“ (Familiaris consortio, bod 13). 
Podriadenosț ženy mužovi, o ktorej na viacerých miestach píše sv. Pavol, nechápe Ján Pavol II. ako dominanciu muža nad ženou, ale ako reciprocitu a komplementárnost'.

Podla Jána Pavla II. muž aj žena boli stvorení v spoločnom človečenstve, avšak s rozdielmi, ktoré determinujú ich mužskost' a ženskost'. A práve $\mathrm{z}$ tejto jednoty $\mathrm{v}$ rozdielnosti pramení reciprocita medzi mužom a ženou, ktorá vedie $\mathrm{k}$ medziosobnému spoločenstvu (communio personarum) (porov. Mulieris dignitatem, b. 7). V takomto koncepte mužskosti a ženskosti niet priestoru pre nadvládu jedného nad druhým.

\section{Záverečné zhrnutie v kontexte súčasných pohladov na postavenie ženy $\mathrm{v}$ modernej spoločnosti}

Ak zhrnieme predchádzajúcu argumentáciu, prichádzame k záveru, že Pavlovo učenie o podriadenosti ženy mužovi spôsobovalo v tradícii Cirkvi nemalé problémy. Duch Svätý ju však v priebehu stáročí viedol a posúval chápanie vztahu medzi mužom a ženou v manželstve:

- od neprijatelných pohanských a judaistických konceptov, ktoré diskriminovali ženu,

- cez postoje, ktoré žene priznávali rovnakú dôstojnost’ ako mužovi vd’aka vykupitel'skému dielu Božieho Syna (hoci postavenie ženy v Cirkvi a spoločnosti bolo nedostatočné),

- až po chápanie, ktoré geniálne vyjadril sv. Ján Pavol II. vo svojej teológii tela.

Vztah medzi mužom a ženou je teda vztahom vzájomnej podriadenosti v láske. Ked' totiž manželia žijú sviatostné manželstvo, ktoré je odrazom Božej lásky a symbolom vztłahu medzi Kristom a Cirkvou, vytvárajú spoločenstvo osôb (communio personarum). V ňom sa ich rozdielnost’ muža a ženy vzájomne doplña a vytvára harmóniu.

Takéto chápanie je schopné priniest’ oslobodenie do hodnotového chaosu súčasnej spoločnosti, ktorá (aj pod výrazným vplyvom gender 
ideológie) znejasnila identitu muža a ženy a ich vzájomné spolužitie deformuje protichodnými tendenciami: bud' diskrimináciou a ponižovaním žien alebo feministickým vyzdvihovaním ženy.

Návrat k inšpirovaným biblickým textom ${ }^{33}$, vysvetlovaným pomocou Magistéria, je spolahlivým prostriedkom na získanie pravdivého poznania (a následne aj konania); a to aj v pálčivých otázkach manželského a rodinného života.

\section{Abstrakt}

Hlavným cielom predloženej prednášky je poskytnút prostredníctvom tradície Cirkvi interpretáciu vážneho sociálneho problému, ktorý apoštol Pavol predostrel vo svojich listoch, najmä v Liste Efezanom (Ef 5, 21-33) - a to podriadenosé ženy mužovi.

Prednáška má tri časti:

Pavlov pohlad na podriadenost ženy mužovi v historických okolnostiach 1. storočia krestanstva.

Pohlad tradície Cirkvi na vztah muža a ženy od poapoštolskej doby až po pápežov 21. storočia.

Záverečné zhrnutie v kontexte súčasných pohladov na postavenie ženy v modernej spoločnosti.

V nosnej prvej časti prednášky poukazujeme na Pavlovo chápanie vztahu Krista a Cirkvi, ktorý on sám označuje ako vel'ké tajomstvo. Rovnako aj vzt̉ah muža a ženy v manželstve vidí ako „mysterium”, ktoré vo svete sprítomňuje „mysterium salutis” (tajomstvo spásy). Pavol hodnotí ludské manželstvo v kontexte Krista a Cirkvi, čo znamená, že manželstvo je obrazom zmluvy Boha a vyvoleného národa, ako aj zmluvy Ježiša Krista a jeho Cirkvi.

${ }^{33}$ Praktický dovetok k predloženej prednáške o tom, ako riešit problémy rodinného života: „Domáce cirkvi môžu byt riešením... Domáce cirkvi sa delia o Bibliu. Z Božieho slova čerpajú svetlo a silu do každodenného života [...] rodiny ako domáce cirkvi sú povolané odovzdávat vieru vo svojom okolí [...] Rodiny sú prví a najlepší poslovia evanjelia rodiny. Sú cestou Cirkvi“. Walter Kasper, Prejav pred kardinálskym konzistóriom 24.02.2014. 
Je teda obrazom „zmluvy novej a večnej”, t.j. vel'konočnej. Touto argumentáciou (Ef 5, 21-33) Pavol poukazuje na mystickú vznešenost̉ manželstva.

Na základe kristologickej a soteriologickej argumentácie Listu Efezanom nadobúda teda problematika podriadenosti ženy mužovi novú dimenziu - nejde tu o prvoplánovú podriadenost ženy, ale o vzájomnú podriadenost̉ medzi mužom a ženou.

V tomto vidíme geniálnost vysvetlenia vzájomných vztahov medzi manželmi, ktoré nie sú ani diskriminačné, ani rovnostárske, ale komplementárne. Mužovi aj žene prisudzujú rovnoprávnost’ a rovnakú dôstojnost’; zároveň však mužovi a žene pripisujú vlastné, špecifické, rozdielne a nenahraditelné úlohy, ktoré im daroval Boh.

Pavlovo učenie o podriadenosti ženy mužovi spôsobovalo v tradícii Cirkvi nemalé problémy. Duch Svätý ju však v priebehu stáročí viedol a posúval chápanie vztahu medzi mužom a ženou v manželstve:

- od neprijatelných pohanských a judaistických konceptov, ktoré diskriminovali ženu;

- cez postoje cirkevných otcov, ktoré žene priznávali rovnakú dôstojnost̉ ako mužovi vdaka vykupitel'skému dielu Božieho Syna; avšak hodnota ženy v Cirkvi a spoločnosti bola nedostatočne oceňovaná;

- až po geniálnu náuku sv. Jána Pavla II. v teológii tela: vztah medzi mužom a ženou v manželstve je vztahom vzájomnej podriadenosti v láske, ktorá je odrazom Božej lásky a symbolom vztahu medzi Kristom a Cirkvou. Tento vztah je vo svojej podstate „communiou personarum" (spoločenstvo osôb), v ktorom sa rozdielnosť ženy a muža vzájomne doplña a vytvára harmóniu.

Prednáškou sme chceli poukázat na fakt, že návrat k inšpirovaným biblickým textom vysvetlovaným pomocou Magistéria je spolahlivým prostriedkom na získanie pravdivého poznania aj v pálčivých otázkach manželského a rodinného života.

\section{Klúčové slová}

Inšpirácia, tradícia, muž, žena, manželstvo, podriadenost', List Efezanom, Pavol 


\section{Abstract}

\section{Interpretation of the Revealed Word by the Tradition of the Church - the Issue of Subordination of Woman to Man in the Saint Paul's Letter to the Ephesians (Eph 5:21-33)}

The main objective of the present lecture is to provide, by the means of the Church tradition, the interpetation of a serious social problem which the Apostle Paul introduced in his letters, especially in the Letter to the Ephesians (Eph 5:21-33) - the issue of the subordination of woman to man.

The article has three parts:

1. Paul's view on the suborditation of female to male in the historical circumstances of the first century of Christianity.

2. The view of the Church tradition on the relation between men and women from the post-apostolic era to the 21 st century popes.

3. Concluding summary in the context of current views on the status of women in modern society.

In the first and principal part of the article we point to Paul's understanding of the relationship of Christ and the Church which he himself describes as a great secret. Also the relationship of man and woman in marriage he considers a "mystery" that represents "mysterium salutis" (mystery of salvation) in the world. Paul judges human marriage in the context of Christ and the Church which means that it is an image of the covenant between God and the chosen people as well as the covenant between Jesus Christ and his Church. It is thus the image of "the new and eternal covenant", i.e. the paschal one. With this reasoning (Eph 5:21-33) Paul refers to the mystical grandeur of marriage.

The issues of the subordination of woman to man based on the Christological and soteriological argument of the Letter to the Ephesians gains a new dimension - it is not about a superficial subordination of women, but about mutual subordination between husband and wife. Here we can see a brilliant illustration of mutual relations between spouses which are neither discriminatory nor egalitarian but complementary. They atribute to man and woman equality and equal dignity. At the same time, they atribute to them their own, specific, distinct and irreplaceable roles given to them by God.

Paul's teaching about the subordination of woman to man had caused considerable problems in the tradition of the Church. The Holy Spirit, however, led her over the centuries and shifted understanding of the relationship between man and woman in marriage:

- from the unacceptable pagan and Judaic concepts that discriminate women, 
- through the attitudes of the Church Fathers, which declared the same dignity of man and woman through the redemptive work of the Son of God; however, the value of women in the Church and society was not appreciated sufficiantly;

- to the ingenious doctrine of St. Pope John Paul II. in his theology of the body: the relationship between man and woman in marriage is a relationship of mutual subordination in love, reflecting God's love and symbolizing the relation between Christ and the Church. This relationship is inherently "communio personarum" (communion of persons) in which the dissimilarity of women and men is mutually complemented and creates harmony.

In this article we wanted to highlight the fact that a return to the inspired biblical texts explained by the Magisterium is a reliable means of obtaining true knowledge even of the thorny issue of conjugal and family life.

\section{Keywords}

Inspiration, tradition, man, woman, marriage, subordination, Letter to the Ephesians, Paul

\section{References}

Ambróu, Hexameron (Corpus Scriptorum Ecclesiasticorum Latinorum, 32).

Bazil Velký, Homilia in martyrium Julittam, [v:] Patrologia Graeca, vol. 31.

Benedikt XVI., Posolstvo Pápežskej biblickej komisii, http://www.tkkbs.sk/view. php?cisloclanku=20120423030.

Dolista J., Naděje vložená do manželství, Olomouc 1994.

Fabris R., Il matrimonio cristiano, [v:] A. Sacchi, Lettere Paoline e altre Lettere, vol. VI., Leumann-Torino 1996.

Fulla M., Antropológia ženy, Bratislava 2004.

Heriban J., Príručnýlexikón biblických vied, Rím 1992.

Hieronym, Listy IV, 148, 25-27 (Celanzii).

Hoppe R., List Efezanům. List Kolosanům, Kostelní Vydř́í 2000.

Kasper W., Prejav pred kardinálskym konzistóriom 24.02.2014.

Klement Alexandrijský, Paedagogus (Corpus Christianorum Series Latina, 70).

Léon-Dufour X., Slovník biblickej teológie, Zagreb 1990.

Mattioli U., La tradizione nella „Mulieris dignitatem“, Genova 1991. 
Paoli U. E., Vita romana, Milano 1982.

Pápežská biblická komisia, Inšpirácia a pravdivost' Svätého písma, 2014.

Pius XII., Príhovory mladomanželom.

Průvodce životem, Pavlìv list do Efezu, Praha 1995.

Ravasi G., Lettere agli Efesini e ai Colossesi, Bologna 1994.

Stott J. R. V., Výklad epištoly Efežanum, Praha 1992.

Vood A. S., Ephesians, Grand Rapids, Michigan 1976 (The Expositor's Bible Commentary, 11).

Weiser A., Die Frau im Umkreis Jesu und in den urchristlichen Gemeinden, [v:] H. Pissarek-Hudelist (Hrsg.), Die Frau in der Sicht der Anthropologie und Theologie, Düsseldorf 1989. 